\title{
EDITORIAL
}

\section{THE SOLDIER IN A HOSTILE ENVIRONMENT}

This was the title of the exhibit which was prepared by the Royal Army Medical College for the British Medical Association's 1969 Scientific Exhibition, held in July, in Aberdeen (see page 162).

It was postulated that enemy action is but one of the elements of hostility to which the soldier may be exposed, and that there are other potential hazards, which, if the appropriate action is not taken to prevent or minimise their effects, can, separately or in combination, operate to deprive a commander of the services of his men. Such influences may be classified as biological, physical, chemical and psychological.

In the first of these, man's vulnerability to invasion by ecto- and endo-parasites, the range extending downwards to the most minute members in the imcrobiological field, has been a matter of concern for many years. Innumerable lectures to medical and non-medical audiences have been effectively illustrated by comparison of battle casualties and manpower wastage due to the ravages of enteric fever in South Africa, and in more recent years, malaria in South East Asia. In general, there are well established principles for dealing with such hazards - but do we know all of the " biological" answers, What, for example, of the reaction of homo sapiens to his rapid transportation over a number of time-zones (Adam, 1969). Of immediate concern to the Army-just how efficient will be the soldier after such a move? If his efficiency is indeed impaired-and the preliminary results of the research programme currently undertaken by Adam and his co-workers in the Royal Army Medical College Department of Applied Physiology and elsewhere, would appear to indicate that this is so-what period of adjustment will be required at the destination to restore the status quo? Is it possible that some form of "immunization" (for want of a better word) to travel can be developed-a re-setting of the biological clock-rather on the lines of artificial acclimatization to heat? Such are the questions to which our commanders may require an answer. ,

In the physical field, a problem which is very much of current interest is that of acoustic trauma, which is dealt with in two papers in this issue of the Journal (Brasher, page 163, and Brasher, Coles, Elwood and Ferres, page 172). This certainly is a matter on which we have no right to be complacent. As Brasher points out, the soldier of today is exposed to greatly increased noise levels of both impulsive and continuous noise. Clearly, every effort must be made to combat their effects, which may lead not only to military inefficiency, but to a considerable degree of human suffering.

Have we identified all of the potentially adverse chemical influences? For example, carbon monoxide poisoning initiated by a slow-conbustion stove in an ill-ventilated barrack room may be reasonably regarded as unlikely to-day, but, on the other hand. this same gas may appear in injurious, if not lethal concentration under other conditions of military service-in vehicles, in arctic tents and so on.

Last, but by no means least, what of the psychological effects of the demands of service life. What of stress-not necessarily restricted to that which may be anticipated under battle conditions? What of boredom, or isolation?

What does all this add up to? Certainly not as attributed by A.A. Milne to Alice when speaking to Christopher Robin ' a soldier's life is terrible hard '. Rather that if the Army Medical Services are to maintain and further their contribution to what a 
senior officer of our Corps once put to the writer as " the maintenance of the man", we must not relax in our efforts to seek out and study the various areas of risk, and to base our advisory and executive functions accordingly.

REFERENCE

AdAM, J. M. (1969). J. roy. Army med. Cps. 115, 14.

\section{THE R.A.M.C. HISTORICAL MUSEUM APPEAL}

Reproduced below is the text of a letter written by Lieutenant-General Sir Norman Talbot, K.B.E., T.D., Q.H.S., M.B., F.R.C.O.G., Chairman of the R.A.M.C. Historical Museum Appeal Committee. It is published as a reminder to all who have not yet contributed to this worthy cause. Donations should be sent to the D.G.A.M.S., Ministry of Defence (AMD), Lansdowne House, Berkeley Square, London, W.1.

Shortly before I took over as D.G.A.M.S. my predecessor, Lieutenant-General Sir Robert Drew, launched an Appeal with a two-fold object:-

To bring the Museum Endowment Fund up to $£ 2,500$, and thereby qualify for a second grant of $£ 500$ from the Ogilby Trust, thus establishing an Endowment Fund of $£ 3,000$.

To create a Museum Development Fund, to be known as "The Barnsley Development Fund", as a tribute to the late Major-General Eric Barnsley, C.B., M.C., by whose untiring effort and financial help the Museum was created.

As a result of a gratifying initial response the first objective was quickly achieved, and to date a sum of $£ 2,541$ has been contributed towards the target of $£ 5,000$ set for the second objective, the Barnsley Development Fund.

This sum has been achieved by the generous response of the R.A.M.C. Corps Mess Fund, the R.A.M.C. Association, Unit Messes, and many retired and serving officers. The money-raising activities of the R.A.M.C. Training Centre in particular have been most praiseworthy and are reflected in their munificent contribution.

This letter comes as a reminder to those who have not yet contributed, and is particularly addressed to Units and Messes at Home and Overseas. If all follow the example of those who have already contributed, the target will be reached without having to appeal to outside bodies. Surely this is something the Corps should be able to achieve?

Colonels Commandant, R.A.M.C.

Major-General J. P. Douglas, C.B., O.B.E., M.B., has been appointed Colonel Commandant, Royal Army Medical Corps, in succession to Major-General T. F. M. Woods. 


\section{BRITISH MEDICAL ASSOCIATION-SCIENTIFIC EXHIBITION}

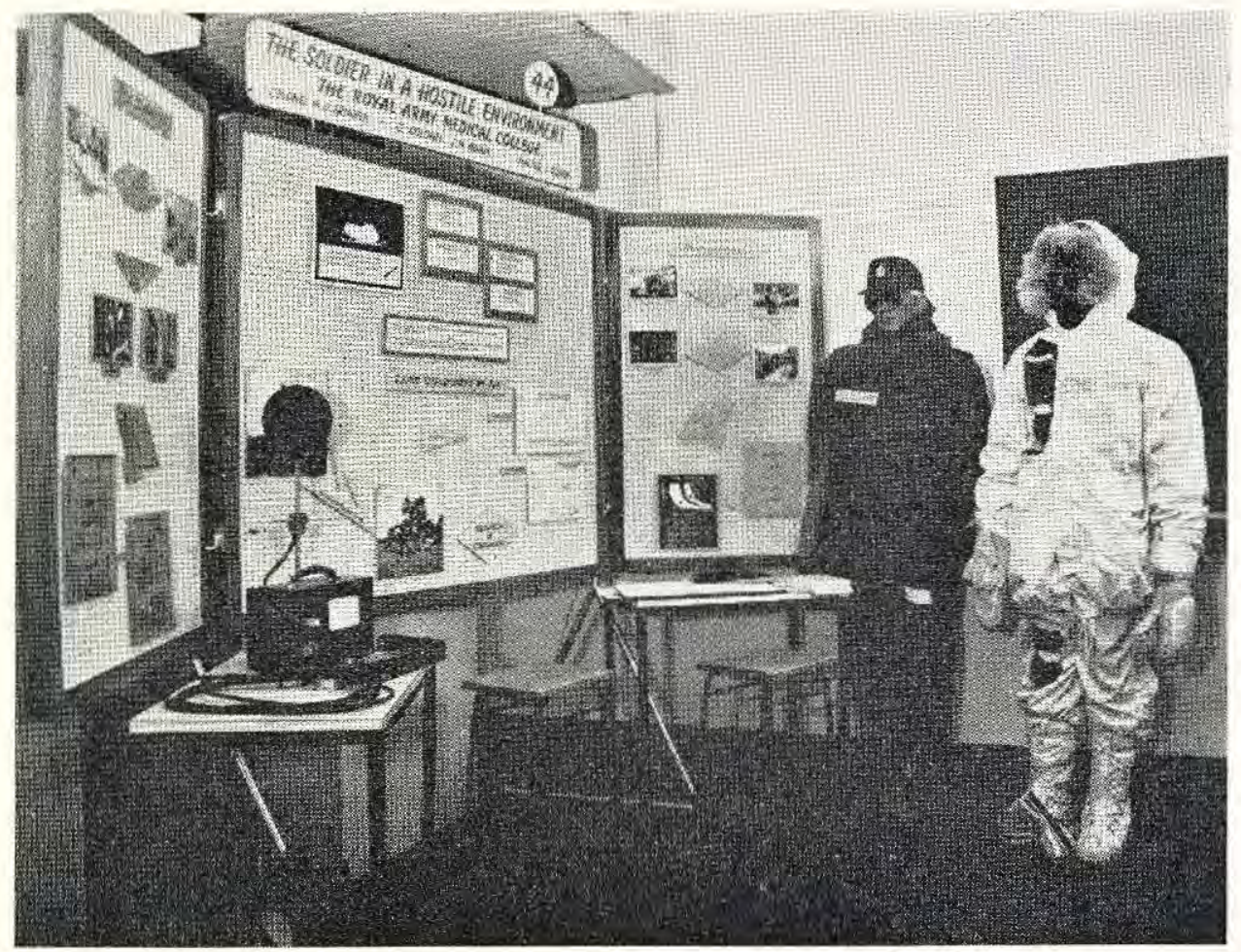

Scotpix, Aherdeen

The soldier in a hostile environment

The British Medical Association's Scientific Exhibition was held in Aberdeen from 7 to 10 July 1969.

The Rnyal Army Medical College presentation, which was awarded a certificate of merit with high commendation, sought to illustrate that enemy action is but one hostile element in the soldier's life. Others may be biological, chemical, physical or psychological. Hot and cold climates, as physical challenges, were illustrated in terms of the risk, the results of taking the risk, and measures adopted in reducing the risk. Another, long distance travel by air at short notice, and its effect on the fighting efficiency of the soldier is the subject of current investigation, of which some preliminary results were presented.

The team, as named in the picture, was completed by Lieutenant-Colonel D. H. McFerran, who took Major Quinn's place, just prior to the Exhibition. 